\title{
High-Risk Recurrence Basal Cell Carcinoma: Focus on Hedgehog Pathway Inhibitors and Review of the Literature
}

\author{
Elena Campione ${ }^{\mathrm{a}}$ Monia Di Prete $^{\mathrm{b}}$ Flavia Lozzi $^{\mathrm{a}}$ Caterina Lanna ${ }^{\mathrm{a}}$ \\ Giulia Spallone $^{\mathrm{a}}$ Mauro Mazzeo $^{\mathrm{a}}$ Terenzio Cosio $^{\mathrm{a}}$ Cristina Rapanotti $^{\mathrm{c}}$ \\ Emi Dika $^{d}$ Roberta Gaziano ${ }^{\text {e }}$ Augusto Orlandi $^{b}$ Luca Bianchi $^{a}$ \\ ${ }^{a}$ Dermatologic Unit, Department of Systems Medicine, University of Rome Tor Vergata, Rome, Italy; ${ }^{b}$ Anatomic \\ Pathology Unit, Department of Biomedicine and Prevention, University of Rome Tor Vergata, Rome, Italy;

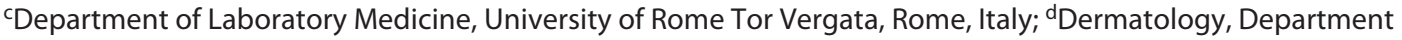 \\ of Experimental, Diagnostic and Specialty Medicine, University of Bologna, Bologna, Italy; ${ }^{\text {Department of }}$ \\ Experimental Medicine, University of Rome Tor Vergata, Rome, Italy
}

\section{Keywords}

Recurrence basal cell carcinoma - Hedgehog pathway . Vismodegib · Sonidegib

\begin{abstract}
Basal cell carcinoma is the most common skin tumour, with the majority of the cases occurring on the head and neck district, where cosmetic and functional results are crucial. It can be locally destructive if not diagnosed early and treated appropriately. Surgery is the treatment of choice for most lesions, but aggressive, recurrent, or unresectable tumours can be challenging to manage. Advanced basal cell carcinoma includes high recurrence risk subtypes, in which standard therapies demonstrate lack of efficacy. This led to a need for investigating more deeply the pathogenesis of the disease and to the discovery of the implication of the hedgehog pathway. The development of systemic inhibitors of this pathway provides new treatment options for patients with advanced disease, resulting in survival improvement. Food and Drug Administration, before, and European Medicines Agency later approved 2 Hedgehog pathway inhibitors for the treatment of advanced basal cell carcinomas, vismo-
\end{abstract}

degib and sonidegib. Here, we present a review of the current English language literature trying to analyze differences in the 2 drugs as a head-to-head comparison between them has not already been documented in a randomized controlled clinical trial. Although vismodegib and sonidegib showed similar efficacy and safety profiles, in an indirect comparison scenario, sonidegib has shown slightly better outcomes in locally advanced basal cell carcinoma than vismodegib. They present different molecular structures, as they bind different residues on their targets and develop resistance for different mutations. In a future scenario, clinical trials comparing the 2 drugs are needed, as well as expanding data on discontinuation of therapy and/or consequential administration of them, with the aim to improve our clinical practise.

(c) 2020 S. Karger AG, Basel

\section{Introduction}

Basal cell carcinoma (BCC) is the most common nonmelanoma skin cancer worldwide. It derives from the cells of the epidermal basal layer either interfollicular or of the hair follicle [1]. For the vast majority of the neo-

karger@karger.com
www.karger.com/che
Karger ${ }^{\prime / 5}$


Table 1. Histopathological features of low-risk recurrence BCC subtypes

\begin{tabular}{ll}
\hline Histotype & Microscopic features \\
\hline Superficial & Superficial lobules of basaloid cells with peripheral palisading \\
& Connection with epidermis \\
& Confinement to papillary dermis \\
& Loose fibromyxoid stroma \\
& Retraction artefacts \\
\hline Nodular & Islands of basaloid cells with peripheral palisading and central haphazard \\
& nuclear arrangement \\
& Deep invasion of the dermis \\
& Sometimes prominent keloidal stroma \\
& Retraction artefacts \\
& Variants: keratotic (nests with central keratinization), nodulocystic (nests \\
& with cystic degeneration), adenoid (cribriform nests) \\
\hline Pigmented & Classic BCC subtypes with superimposed pigmentation \\
\hline BCC with adnexal differentiation & Follicular, sebaceous, apocrine, or eccrine gland differentiation \\
& Matrical: shadow cells \\
& Infundibulocystic: anastomosing cords of basaloid cells with infundibular \\
cyst-like structures & Sebaceous: mature sebocytes (EMA+) \\
Ductal: apocrine or eccrine sweat gland duct resemblance \\
Apocrine: decapitation secretion \\
Eccrine: ducts with cuticle (CEA+ and EMA+) \\
Delicate and anastomosing strands of basaloid cells \\
Connection with epidermis \\
Abundant fibroblastic stroma \\
\hline
\end{tabular}

BCC, basal cell carcinoma.

plasms, surgical excision with free margins is both diagnostic and therapeutic [2]. For a very small proportion of patients, with higher risk of recurrence, the preferred surgical technique is Mohs micrographic surgery [3-6]. These patients may experience advanced BCC (aBCC), including both locally advanced (laBCC) and metastatic (mBCC) disease, which are more difficult to treat and not eligible to nonsurgical topical therapy, as imiquimod or 5-fluorouracil $[7,8]$. The laBCC has been defined, by a multidisciplinary expert group from the UK, as a tumour larger than $2 \mathrm{~cm}$, without lymph node involvement nor metastases, in which current therapies cannot be considered for disease- or patient-driven factors [9]. Among the disease-driven features, there are tumour size and localization (i.e., the mask area of the face is often challenging for the dermatologic surgeons to reach adequate margins), high number of lesions, and histological subtypes (i.e., high-risk histotypes, see below). Patient-driven factors include age, performance status, comorbidities, and genodermatoses (i.e., Gorlin-Goltz syndrome or xeroder- ma pigmentosum). The metastatic risk in $\mathrm{BCC}$ is about $0.0028 \%$. Risk factors for $\mathrm{mBCC}$ are clinical short diameter $\geq 4 \mathrm{~cm}$, deep invasion (beyond fat tissue, mostly following nerve course), high-risk histotypes (i.e., micronodular, infiltrating, and sclerosing/morphoeic), and head and neck site [10-12]. Despite the clinical variability, the microscopic appearance is common to $>20$ histotypes described [13] and consists of islands or nests of basaloid cells, with hyperchromatic nuclei and scant cytoplasm, which exhibit peripheral palisading, surrounded by fibrous stroma. It may present myxoid change, which is responsible for decreasing cohesion between tumour cells and the stroma, leading to the characteristic histopathological retraction artefact after formalin fixation and paraffin embedding of the neoplasm [14]. In the previous WHO Classification of Skin Tumours of 2006, it has been pointed out that several histotypes present increased rate of recurrence due to their infiltrative growth, which can induce the dermatopathologist to underestimate the surgical margins [15]. In the latest edition of the WHO 
Table 2. Histopathological features of high-risk recurrence BBC subtypes

\begin{tabular}{|c|c|}
\hline Histotype & Microscopic features \\
\hline Micronodular & $\begin{array}{l}\text { Small nests of basaloid cells } \\
\text { No connection with epidermis } \\
\text { Scattered nests throughout deep dermis and subcutis } \\
\text { Thin rims of fibrous stroma separate the nests } \\
\text { Irregular and infiltrative peripheral edge } \\
\text { Perineural invasion } \\
\text { Punch biopsies have significant rate of false-negative results }\end{array}$ \\
\hline Infiltrating & $\begin{array}{l}\text { Narrow cords and nests of basaloid cells } \\
\text { Abundant fibrotic stroma } \\
\text { Infiltrative growth pattern at the deep edge } \\
\text { Perineural invasion } \\
\text { Frequent overlap with sclerosing/morphoeic BCC }\end{array}$ \\
\hline Sclerosing/morphoeic & $\begin{array}{l}\text { Narrow cords of basaloid cells } \\
\text { Abundant sclerotic collagenous stroma } \\
\text { Irregular and infiltrative borders } \\
\text { Uncommon retraction artefacts } \\
\text { Perineural invasion } \\
\text { Frequent overlap with infiltrating BCC }\end{array}$ \\
\hline $\begin{array}{l}\text { BCC with sarcomatoid } \\
\text { differentiation }\end{array}$ & $\begin{array}{l}\text { Basaloid epithelial component admixed with malignant mesenchymal component of } \\
\text { various differentiation (osteo, chondro, leio, rhabdo, and pleomorhic undifferentiated) } \\
\text { Similar chromosomal changes in epithelial and mesenchymal components (divergent } \\
\text { mesenchymal differentiation from the epithelial component) }\end{array}$ \\
\hline $\begin{array}{l}\text { Basosquamous } \\
\text { carcinoma }\end{array}$ & $\begin{array}{l}\text { Island of basaloid cells (BerEP4+) admixed with atypical squamous cells with abundant } \\
\text { eosinophilic cytoplasm (EMA+) and transition zones } \\
\text { Cellular fibrotic stroma } \\
\text { Perineural invasion }\end{array}$ \\
\hline
\end{tabular}

BCC, basal cell carcinoma.

Classification of 2018, it has been highlighted the absence of a formal staging system for BCC, although different clinical and histological presentations and response to treatment have been recognized [16]. These aspects permit to stratify the BCC variants in lower and higher risk of recurrence [17]. Low-risk subtypes include superficial, nodular, and pigmented, with adnexal differentiation and fibroepithelioma of Pinkus (Table 1), while high-risk histotypes are micronodular, infiltrating, and sclerosing/ morphoeic, with sarcomatoid differentiation (Table 2). Basosquamous carcinoma is a neoplasm with features of both BCC and squamous cell carcinoma (SCC), which may be considered among the BCC histotypes with higher risk of recurrence [11]. The histopathological differential diagnosis mainly includes follicular-derived basaloid tumours (trichoepithelioma) and SCC with basaloid features. In this setting, immunohistochemical stainings have an important role. Diffuse Bcl-2 and CD10 expression is more frequently encountered in BCC than tricho- epithelioma, while the latter shows commonly CK15, CK20, and podoplanin (D2-40) expression in the peripheral tumour nests [18]. Moreover, the androgen receptor and CK20 expression may be useful to distinguish sclerosing/morphoeic BCC, which shows, respectively, more diffuse and fewer cells' positivity, from desmoplastic trichoepithelioma [19]. BerEP4 (EpCAM) and the epithelial membrane antigen help in the distinction between BCC and basaloid SCC. The former expresses strong BerEP4 and is negative for the epithelial membrane antigen, while the converse is true for the latter [20].

\section{Pathogenesis: Molecular Aspects}

Genetic profiling of BCC reveals that it is one of the neoplasms with the highest rate of somatic mutations showing the UV radiation signature (cytosine-thymine substitutions) [21]. The incidence of BCC peaks at 
Table 3. Criteria to define patients with BCCs not eligible for surgery or irradiation

$>5$ BCCs, if patient suffers from genetic syndromes

BCC $>10 \mathrm{~mm}$, relapsing after 2 surgeries in critical locations (e.g., periocular and perioral areas)

BCC infiltrating in bones/cartilages/other structures and curative resection unlikely

Relapsing BCC after multiple surgeries and/or radiotherapy

Advanced BCC in patients who do not qualify for general anaesthesia

BCC, basal cell carcinoma.

30,000 h of cumulative sun exposure, particularly when intermittent and during childhood, and then flattens, unlike in SCC, in which risk increases proportionally to cumulative sun exposure, without reaching a plateau [22]. A central role in the pathogenesis of BCC is due to the dysregulation of the Hedgehog $(\mathrm{Hh})$ pathway, which has a critical role in the development of the embryo, while in adults is quiescent. It is involved in the maintenance of the somatic stem cells and pluripotent cells' crypt and is fundamental for skin repair [23]. Protein patched homolog 1 (PTCH1) is one of the deregulated protein in the Hh pathway involved in the pathogenesis of BCC. It is a transmembrane receptor protein that blocks migration of transmembrane protein Smoothened (SMO) to the primary cilium, where its accumulation leads to downstream transcription of glioma-associated oncogene (GLI1) transcription factors and increase intracellular calcium ion concentrations [24, 25]. The result is a constitutional suppression of the Hh signalling cascade operated by PTCH1. Hedgehog ligands (Sonic, Indian, and Desert hedgehogs) repress PTCH1 activity, enhancing signalling along the $\mathrm{Hh}$ pathway, but they are normally absent in a physiological state [24]. It has been observed that Hh signalling is abnormal in $95 \%$ of sporadic BCC [26], resulted from the deletion of the PTCH1 gene or the hyperactivation of the SMO [27]. More than 50\% of sporadic BCCs show loss of heterozygosity of the PTCH1 gene, on chromosome 9q22.3, by $\mathrm{UV}$ radiation-induced mutations in the vast majority of cases [28]. Germline mutations in the PTCH1 gene are typical of all the BCCs in patients with nevoid BCC syndrome [29]. It is a rare autosomal dominant condition, driven by nonfunctional copy of $P T C H 1$ inherited or acquired through germline mutations, and is characterized by developmental skeletal and neurological defects associated with a high propensity for neoplasia [30]. The hedgehog pathway is deregulated also in other neoplasm, as chronic myeloid leukemia, non-small-cell lung carcinoma, and medulloblastoma [31-33].

High-Risk Recurrence Basal Cell Carcinoma

\section{Target Therapy: Hedgehog Inhibitors}

Given the diffuse alteration of the Hh pathway in BCC, its inhibitors (HPI) have been studied and approved recently as a first-line therapy for patients with aBCC. Moreover, a joint expert consensus has proposed criteria to define those cases for which surgery or irradiation are not indicated and therapy with systemic HPI is recommended (Table 3) [34]. The first natural HPI identified was the cyclopamine, discovered in corn lily plants, which acts as binding SMO. Cyclopamine resulted to be teratogenic, leading to embryonic craniofacial defects [35]. Subsequently, modifying cyclopamine, patidegib (also called saridegib, IPI-926) was synthesized, which was administered by mouth in a phase I trial, demonstrating a not favourable adverse effect profile [36]. On the other hand, topical administration is followed by tumour shrinkage, in the absence of side effects [37]. Consequently, the research of oral HPI with a better safety profile led to the discovery of vismodegib (GDC-0449) and sonidegib (NVP-LDE225) [38, 39]. Vismodegib and sonidegib are the only targeted oral therapy approved by FDA and EMA for the treatment of aBCC ineligible for curative surgery or radiotherapy [40-42]. Furthermore, other known molecules, such as azole antimycotic compounds, particularly itraconazole, show inhibition of the Hh pathway. Itraconazole suppresses SMO migration and accumulation in the primary cilium [43]. Its efficacy as an oral treatment for BCC was demonstrated in an open-label, exploratory phase II trial [44].

Efficacy and safety of vismodegib have been tested in 3 clinical trials. The pivotal trial ERIVANCE (ClinicalTrials.gov: NCT00833417), a phase II multicentre, single-arm, 2-cohort trial, has been conducted on 104 patients with aBCC, who was administered $150-\mathrm{mg}$ vismodegib once daily. The study showed, at 21 months, an objective response rate (ORR) assessed through RECIST criteria (Central Review) of $47.6 \%$ for laBCC and $33.3 \%$ 
Table 4. Mechanisms of action and of primary and acquired resistance to vismodegib and sonidegib during the treatment of advanced BCC

\begin{tabular}{lll}
\hline Drug & Vismodegib (GDC-0449) & Sonidegib (NVP-LDE225) \\
\hline Action & Selective SMO antagonism [38] & Selective SMO antagonism [39] \\
\hline Primary resistance & SMO G497W mutation [55] & \\
\hline $\begin{array}{l}\text { Drug-specific secondary } \\
\text { resistance }\end{array}$ & $\begin{array}{l}\text { Gain-of-function mutation of GLI [56] } \\
\text { Loss-of-function mutation of SUFU [57] } \\
\text { Novel SMO mutations (D473, E518, W281, V321, }\end{array}$ & $\begin{array}{l}\text { Wmpaired ciliogenesis due to mutation of OFD1 [66] } \\
\text { I408, and C469) [57, 58] }\end{array}$ \\
\hline $\begin{array}{l}\text { Common mechanisms } \\
\text { of secondary resistance }\end{array}$ & Clonal expansion of target therapy-resistant carcinoma cells [57] \\
\hline
\end{tabular}

BCC, basal cell carcinoma; SMO, transmembrane protein Smoothened; GLI, glioma-associated oncogene; SUFU, suppressor of fusion; OFD1, oral-facial-digital syndrome gene 1; SRF-MKL1, serum response factor-megakaryoblastic leukemia 1.

for $\mathrm{mBCC}$, while the Investigator Review ORR was of $60.3 \%$ for laBCC and $48.5 \%$ for $\mathrm{mBCC}$, with a median duration of the response ( $\mathrm{mDOR}$ ) and progression-free survival (PFS) assessed through Central Review of 9.5 months. Discontinuation of the therapy due to adverse events occurred in 22 patients $(21.2 \%)$, while thirtythree deaths (31.7\%) were reported, but none was related to the treatment $[45,46]$. Another multicentre, single-arm, open-label safety trial, STEVIE (ClinicalTrials. gov: NCT01367665), enrolled 1,215 patients, to whom 150-mg vismodegib was administered once daily, and has been considered analogous to real-world experience. It showed that most of the patients had treatmentrelated side effects, including muscle spasms (due to increased intracellular calcium concentrations) [47], alopecia (the Hh signalling pathway is necessary for a correct hair follicle morphogenesis and cycling) [48], dysgeusia (signalling along the $\mathrm{Hh}$ pathway is required for the normal taste bud physiology) [49], weight loss, and asthenia. The ORR assessed through RECIST 1.1 criteria (Investigator Review) $(68.5 \%$ for laBCC and $36.9 \%$ for $\mathrm{mBCC}$ ) and the discontinuation rate due to AEs (31\% of patients) substantially confirmed the results of ERIVANCE [50]. The most recent randomized, double-blind, regimen-controlled trial, MIKIE (ClinicalTrials.gov: NCT01815840), evaluated 2 intermittent schemes of administration of vismodegib in 229 patients with multiple BCCs (not laBCC). Patients were randomized $1: 1$ in the 2 treatment arms. Patients in group A $(n=116)$ received $150-\mathrm{mg}$ vismodegib per day for 12 weeks, followed by 3 rounds of 8 weeks of placebo, and then other 12 weeks of 150 -mg vismodegib daily. Patients in group $\mathrm{B}(n=113)$ received $150-\mathrm{mg}$ vismodegib per day for 24 weeks, followed by 3 rounds of 8 weeks of placebo, and then other 8 weeks of 150 -mg vismodegib daily. The results were evaluated at week 73 when both groups revealed a significant reduction in the number of lesions (62.7\% in group A and $54.0 \%$ in group B), although $23 \%$ of patients discontinued the treatment during the course of the study [51]. Although the results were interesting, the alternative regimens tested in the MIKIE trial in patients with multiple BCC lesions (nonlaBCC) are not approved [42].

In 2015, a multicentre, randomized, double-blind, phase II trial, BOLT (ClinicalTrials.gov: NCT01327053), evaluated efficacy and safety of sonidegib and led to the approval of the drug as a first-line treatment for laBCC $[41,52]$. A total of 230 patients with aBCC were randomized 1:2 into 2 treatment arms. In the first one arm, sonidegib was administered at the dose of $200 \mathrm{mg}$ once daily, while in the second arm, patients received $800 \mathrm{mg}$ of the drug once daily [52]. At 30 months, 200-mg sonidegib demonstrated a better safety-risk profile. Patients receiving $200 \mathrm{mg}$ of therapy had an ORR assessed through the very stringent mRECIST criteria (Central Review) of $56.1 \%$ for laBCC and of $71.2 \%$ assessed through mRECIST (Investigator Review), with a mDOR and a PFS of 26.1 and 22.1 months, respectively. Seventy patients (30.4\%) discontinued the therapy during the trial for AEs, such as muscle spasms, alopecia, dysgeusia, weight loss, and asthenia $[52,53]$. 
Table 5. Comparison between the 2 pivotal studies of vismodegib and sonidegib

\begin{tabular}{|c|c|c|}
\hline Design & $\begin{array}{l}\text { Phase II, multicentre, nonrandomized, } \\
\text { 2-cohort clinical trial }\end{array}$ & $\begin{array}{l}\text { Phase II, multicentre, randomized, } \\
\text { double-blind clinical trial }\end{array}$ \\
\hline BCC severity assessment & RECIST, Central Review & mRECIST, Central Review \\
\hline Study populations & $\begin{array}{l}104 \text { patients, treated with vismodegib } \\
150 \mathrm{mg} \text { daily }\end{array}$ & $\begin{array}{l}230 \text { patients, randomized } 1: 2 \text {, respectively, } \\
\text { to sonidegib } 200 \text { and } 800 \mathrm{mg}^{\text {a }} \text { daily }\end{array}$ \\
\hline Median duration response, months ${ }^{b}$ & $9.5^{c}$ & 26.1 \\
\hline Median progression-free survival, months ${ }^{\mathrm{b}}$ & $9.5^{c}$ & 22.1 \\
\hline 2-year overall survival & 39 months: $85.5 \%$ & 30 months: $93.2 \%$ \\
\hline
\end{tabular}

BCC, basal cell carcinoma; RECIST, Response Evaluation Criteria in Solid Tumors; mRECIST, modified Response Evaluation Criteria in Solid Tumors. ${ }^{a}$ Only $200-\mathrm{mg}$ results are reported because 800 -mg dose is not approved. ${ }^{\mathrm{b}}$ Only locally advanced basal cell carcinoma results are reported. ${ }^{\mathrm{c}}$ In ERIVANCE, only 21 -month analysis was centrally reviewed and then reported here for comparison with sonidegib results.

\section{Resistance to HPI}

Mutations in the proteins of the Hh signalling pathway are responsible for resistance to HPI or disease recurrence due to escaping mechanisms developed by residual tumour cells. Mutations of SMO are detected in 50\% of patients with resistant disease $[54,55]$. Data obtained by competition binding assays show a significant decrease in the affinity of both vismodegib and sonidegib when $D 473 A$ mutation of $S M O$ is present [56]. If E518A mutation of $S M O$ occurs, there is a significant drop in the binding affinity only for vismodegib, while it increases slightly for sonidegib [56]. Moreover, by means of computational docking of vismodegib onto the SMO protein, it has been revealed that the mutation W281, V321, I408, and C469 are closely located to the drug-binding pocket and negatively affect the affinity of the drug for its molecular target $[57,58]$. GLI1 gene copy number changes were also found and implicated in the resistance to HPI [57] (Table 4). Switching to alternative therapies or using a combination of drugs (i.e., combining sonidegib and itraconazole in patients with vismodegib-resistant neoplasm [59] or arsenic trioxide associated with itraconazole in patients with disease relapse after SMO inhibitors [60]) may be strategies to bypass the raising of therapy resistance.

\section{Comparison between Sonidegib and Vismodegib in aBCC}

The comparison between vismodegib and sonidegib has not been already documented in a randomized controlled clinical trial, while it could be useful to improve our clinical practise. In Europe, vismodegib is approved for the treatment of laBCC and $\mathrm{mBCC}$, while sonidegib is approved for the treatment of laBCC.

We analyzed different end-points of ERIVANCE and BOLT studies (Tables 5 and 6). The 2 pivotal studies show some structural differences. First, the drugs were administered in different dosage (vismodegib $150 \mathrm{mg}$ once daily and sonidegib 200 or $800 \mathrm{mg}$ once daily). Also, the followup was of different length (39 months in ERIVANCE and 42 months in BOLT). Different criteria were adopted to assess BCC severity. In ERIVANCE, it was applied the Response Evaluation Criteria in Solid Tumors (RECIST), Version 1.0, as assessed by computed tomography or magnetic resonance [61]. In BOLT, a modified more stringent version of the RECIST, mRECIST, was adopted. This resolves a number of issues arisen from the release of RECIST guidelines, including the number of lesions (which was not previously assessed, evaluating only the target lesion) and pathological lymph nodes [62]. Finally, patient populations enrolled in the 2 different studies were heterogeneous; therefore, a comparing analysis could result in statistical bias. A matching adjusted indirect compari- 
Table 6. Comparison between the 2 pivotal studies of vismodegib and sonidegib

\begin{tabular}{|c|c|c|}
\hline Design & $\begin{array}{l}\text { Phase II, multicentre, nonrandomized, } \\
\text { 2-cohort clinical trial }\end{array}$ & $\begin{array}{l}\text { Phase II, multicentre, randomized, } \\
\text { double-blind clinical trial }\end{array}$ \\
\hline BCC severity assessment & RECIST, Investigator Review & RECIST-like, Investigator Review \\
\hline Study populations & $\begin{array}{l}104 \text { patients, treated with vismodegib } \\
150 \mathrm{mg} \text { daily }\end{array}$ & $\begin{array}{l}230 \text { patients, randomized } 1: 2 \text {, respectively, } \\
\text { to sonidegib } 200 \text { and } 800 \mathrm{mg}^{\text {a }} \text { daily }\end{array}$ \\
\hline Median duration response, months ${ }^{\mathrm{b}}$ & $26.2^{\mathrm{c}}$ & $15.7^{\mathrm{c}}$ \\
\hline Median progression-free survival, months ${ }^{\mathrm{b}}$ & $12.9^{\mathrm{c}}$ & $19.35^{\mathrm{c}}$ \\
\hline 2-year overall survival & 39 months: $85.5 \%$ & 30 months: $93.2 \%$ \\
\hline
\end{tabular}

son technique has been proposed in 2017, trying to reduce intrinsic confounder factors [63]. Conforming BOLT results using RECIST-like criteria resulted that patients with laBCC treated with 200-mg sonidegib (approved dose) showed a slightly higher ORR (59.5 vs. $47.6 \%$ ), a longer median progression-free survival (mPFS) (22.1 vs. 9.5 months), and longer mDOR (15.7 months vs. not estimable) than those in therapy with vismodegib [63].

In both pivotal studies, vismodegib and sonidegib showed high patient discontinuation percentages of around 50\% vismodegib: $21.2 \%$ due to AEs, $26 \%$ due to patient decision, and $9.8 \%$ due to physician decision; sonidegib: $30 \%$ due to AEs, $10 \%$ due to patient decision, and $13 \%$ physician decision) (Lear et al. [53], Sekulic et al. [46]). The first AEs registered during treatment with vismodegib were dysgeusia and fatigue with sonidegib [45, $46,52,53]$. Data from both pivotal studies showed that sonidegib had an approximately $10 \%$ lower incidences of most AEs compared with vismodegib, and the time to onset of AEs also indicated that patients treated with sonidegib may experience AEs slightly later than with vismodegib [34]. For management of adverse effects, sonidegib is the only HPI that offers in label the option for dose modification (alternative dosing): $200 \mathrm{mg}$ every other day.

Finally, it is possible to discuss the main pharmacokinetic profiles of the 2 drugs and some differences in the clinical outcome. Sonidegib shows a higher half-life of vismodegib and plasma levels dependent on the dose ad- ministered. In fact, vismodegib plasma levels correlate with alpha-1-acid glycoprotein (AAG), which once saturated leads the drug to bind serum albumin. The consequence is that a higher dosage of vismodegib does not increase the free drug plasma level [34, 42]. Differently, increasing sonidegib dosage leads to an increment of free drug plasma level until the absorption limit. Moreover, sonidegib seems to be more lipophilic than vismodegib suggesting a greater skin distribution. Despite the longer half-life of sonidegib, the full effect of an interruption or dose adjustment of sonidegib on several adverse events is expected to generally occur after a few weeks. The median time to resolution of CK level elevation (to normalization or grade 1) is 12 days (95\% CI: 8-14 days) [41]. Topical formulations of vismodegib and sonidegib have been tested, trying to bypass systemic AEs and increase local biodisponibility [64, 65]. A double-blind, vehicle-controlled study had also taken place, enrolling 8 patients with Gorlin-Goltz syndrome and multiple aBCCs treated with $0.75 \%$ sonidegib cream or vehicle twice daily, with scarce results [65]. Currently, no topical HPI is available for clinical use.

\section{Conclusion}

Vismodegib and sonidegib showed similar efficacy and safety profiles and the analogue spectrum of AEs. The drugs present different molecular structures, and a comparison 
between them is useful for clinical purpose. The opportunity to analyze them in parallel gives us more therapeutic options as they bind different residues and develop resistance because of different mutations. Therefore, in case of primary and/or acquired resistance, in terms of tumour relapse, a switch from one drug to the other may be useful. In addition, it also could be of interest to associate vismodegib or sonidegib to other drugs that have impact on the $\mathrm{Hh}$ pathway, such as itraconazole and arsenic trioxide, as already reported in the literature. Although sonidegib has shown slightly better outcomes than vismodegib in laBCC, in a future scenario, clinical trials comparing the 2 drugs are needed, as well as further studies on discontinuation of therapy and/or consequential administration of them.

\section{Disclosure Statement}

The authors declare no conflicts of interest to declare.

\section{Funding Sources}

This research was made possible by an unrestricted grant from Sun Pharmaceuticals.

\section{Author Contributions}

E.C., M.D.P., F.L., and C.L. wrote the manuscript. G.S., T.C., C.R., E.D., and R.G. collaborated in the research. A.O. and L.B. supervised the research.

\section{References}

1 Donovan J. Review of the hair follicle origin hypothesis for basal cell carcinoma. Dermatol Surg. 2009 Sep;35(9):1311-23.

2 Dika E, Fanti PA, Ismaili A, Misciali C, Vaccari S, Barisani A, et al. Basal cell carcinoma margin delineation: is curettage useful? A surgical and histological study. J Dermatolog Treat. 2013 Jun;24(3):238-42.

3 Trakatelli M, Morton C, Nagore E, Ulrich C, Del Marmol V, Peris K, et al. Update of the European guidelines for basal cell carcinoma management. Eur J Dermatol. 2014 Jun;24(3): $312-29$.

4 Dika E, Fanti PA, Venturi M, Baraldi C, Patrizi A. Non-melanoma skin cancer: to Mohs or not to Mohs? G Ital Dermatol Venereol. 2015 Oct;150(5):630-2.

5 Dika E, Fanti PA, Christman H, Ravaioli GM, Patrizi A. Videodermoscopy and curettage: the value of simple procedures during Mohs surgery. Dermatol Surg. 2017 Dec;43(12): 1411-7.

6 Kauvar AN, Cronin T, Roenigk R, Hruza G, Bennett R; American Society for Dermatologic Surgery. Consensus for nonmelanoma skin cancer treatment: basal cell carcinoma, including a cost analysis of treatment methods. Dermatol Surg. 2015 May;41(5):550-71.

7 Campione E, Di Prete M, Del Principe I, Diluvio L, Citarella L, Orlandi A, et al. Lack of efficacy of imiquimod in patients with basal cell carcinoma previously treated with rituximab for B cell lymphoma: two case reports. J Med Case Rep. 2016 Mar; 10:57.

8 Diluvio L, Lanna C, Lozzi F, Palumbo V, Bianchi L, Campione E. Basal cell carcinomas treated with $0.5 \% 5$-fluorouracil and $10 \%$ salicylic acid topical solution. Dermatol Ther. 2019;32(3):e12908.

9 Lear JT, Corner C, Dziewulski P, Fife K, Ross GL, Varma S, et al. Challenges and new horizons in the management of advanced basal cell carcinoma: a UK perspective. Br J Cancer. 2014 Oct;111(8):1476-81.
10 Morgan FC, Ruiz ES, Karia PS, Besaw RJ, Neel VA, Schmults CD. Factors predictive of recurrence, metastasis, and death from primary basal cell carcinoma $2 \mathrm{~cm}$ or larger in diameter. J Am Acad Dermatol. 2019 Oct.

11 Cameron MC, Lee E, Hibler BP, Barker CA, Mori S, Cordova M, et al. Basal cell carcinoma: epidemiology; pathophysiology; clinical and histological subtypes; and disease associations. J Am Acad Dermatol. 2019;80(2):303-17.

12 Walling HW, Fosko SW, Geraminejad PA, Whitaker DC, Arpey CJ. Aggressive basal cell carcinoma: presentation, pathogenesis, and management. Cancer Metastasis Rev. 2004 Dec;23(3-4):389-402.

13 Saldanha G, Fletcher A, Slater DN. Basal cell carcinoma: a dermatopathological and molecular biological update. Br J Dermatol. 2003 Feb;148(2):195-202.

14 AbdullGaffar B. The prevalence and importance of clefts in cutaneous neoplasms. Pathology. 2012 Apr;44(3):267-70.

15 Rippey JJ, Rippey E. Characteristics of incompletely excised basal cell carcinomas of the skin. Med J Aust. 1997 Jun;166(11):581-3.

16 Stockfleth E, Sterry W. New treatment modalities for basal cell carcinoma. Recent Results Cancer Res. 2002;160:259-68.

17 Bichakjian CK, Olencki T, Aasi SZ, Alam M, Andersen JS, Berg D, et al. Basal cell skin cancer, version 1.2016, NCCN clinical practice guidelines in oncology. J Natl Compr Canc Netw. 2016;14(5):574-97.

18 Tebcherani AJ, de Andrade HF, Sotto MN. Diagnostic utility of immunohistochemistry in distinguishing trichoepithelioma and basal cell carcinoma: evaluation using tissue microarray samples. Mod Pathol. 2012 Oct;25(10):1345-53.

19 Katona TM, Perkins SM, Billings SD. Does the panel of cytokeratin 20 and androgen receptor antibodies differentiate desmoplastic trichoepithelioma from morpheaform/infiltrative basal cell carcinoma? J Cutan Pathol. 2008 Feb;35(2):174-9.
20 Webb DV, Mentrikoski MJ, Verduin L, Brill LB, Wick MR. Basal cell carcinoma vs basaloid squamous cell carcinoma of the skin: an immunohistochemical reappraisal. Ann Diagn Pathol. 2015 Apr;19(2):70-5.

21 Jayaraman SS, Rayhan DJ, Hazany S, Kolodney MS. Mutational landscape of basal cell carcinomas by whole-exome sequencing. J Invest Dermatol. 2014 Jan;134(1):213-20.

22 Rosso S, Zanetti R, Martinez C, Tormo MJ, Schraub S, Sancho-Garnier H, et al. The multicentre south European study 'Helios'. II: different sun exposure patterns in the aetiology of basal cell and squamous cell carcinomas of the skin. Br J Cancer. 1996 Jun;73(11):1447-54.

23 Le H, Kleinerman R, Lerman OZ, Brown D, Galiano R, Gurtner GC, et al. Hedgehog signaling is essential for normal wound healing. Wound Repair Regen. 2008 Nov-Dec;16(6): 768-73.

24 Bakshi A, Chaudhary SC, Rana M, Elmets CA, Athar M. Basal cell carcinoma pathogenesis and therapy involving hedgehog signaling and beyond. Mol Carcinog. 2017 Dec;56(12):2543-57.

25 Heo JS, Lee MY, Han HJ. Sonic hedgehog stimulates mouse embryonic stem cell proliferation by cooperation of $\mathrm{Ca} 2+/$ protein kinase $\mathrm{C}$ and epidermal growth factor receptor as well as Gli1 activation. Stem Cells. 2007 Dec;25(12):3069-80.

26 Epstein EH. Basal cell carcinomas: attack of the hedgehog. Nat Rev Cancer. 2008 Oct; 8(10):743-54.

27 Otsuka A, Levesque MP, Dummer R, Kabashima K. Hedgehog signaling in basal cell carcinoma. J Dermatol Sci. 2015 May;78(2):95-100.

28 Reifenberger J, Wolter M, Knobbe CB, Köhler B, Schönicke A, Scharwächter C, et al. Somatic mutations in the PTCH, SMOH, SUFUH and TP53 genes in sporadic basal cell carcinomas. Br J Dermatol. 2005 Jan;152(1):43-51.

29 Verkouteren JAC, Ramdas KHR, Wakkee M, Nijsten T. Epidemiology of basal cell carcinoma: scholarly review. Br J Dermatol. 2017 Aug;177(2):359-72. 
30 Gorlin RJ. Nevoid basal cell carcinoma syndrome (Gorlin syndrome). Orphanet J Rare Dis. 2004 Dec;3(6):32-9.

31 Long B, Zhu H, Zhu C, Liu T, Meng W. Activation of the Hedgehog pathway in chronic myelogeneous leukemia patients. J Exp Clin Cancer Res. 2011 Jan;30:8.

32 Dahlin AM, Hollegaard MV, Wibom C, Andersson U, Hougaard DM, Deltour I, et al. CCND2, CTNNB1, DDX3X, GLI2, SMARCA4, MYC, MYCN, PTCH1, TP53, and MLL2 gene variants and risk of childhood medulloblastoma. J Neurooncol. 2015 Oct; 125(1):75-8.

33 Liu Y, Huber RM, Kiefl R, Tufman A, Kauffmann-Guerrero D. Hedgehog pathway activation might mediate pemetrexed resistance in NSCLC cells. Anticancer Res. 2020 Mar; 40(3):1451-8

34 Dummer R, Ascierto PA, Basset-Seguin N, Dréno B, Garbe C, Gutzmer R, et al. Sonidegib and vismodegib in the treatment of patients with locally advanced basal cell carcinoma: a joint expert opinion. J Eur Acad Dermatol Venereol. 2020 Jan.

35 Cooper MK, Porter JA, Young KE, Beachy PA. Teratogen-mediated inhibition of target tissue response to Shh signaling. Science. 1998 Jun;280(5369):1603-7.

36 Jimeno A, Weiss GJ, Miller WH, Gettinger S, Eigl BJ, Chang AL, et al. Phase I study of the Hedgehog pathway inhibitor IPI-926 in adult patients with solid tumors. Clin Cancer Res. 2013 May; 19(10):2766-74.

37 Epstein EH, Lear J, Saldanha G, Tang JY, Harwood C. Hedgehog pathway inhibition by topical patidegib to reduce BCC burden in patients with basal cell nevus (Gorlin) syndrome. J Clin Oncol. 2018;36(15 Suppl): e21626.

38 Robarge KD, Brunton SA, Castanedo GM, Cui Y, Dina MS, Goldsmith R, et al. GDC0449-a potent inhibitor of the hedgehog pathway. Bioorg Med Chem Lett. 2009 Oct; 19(19): 5576-81.

39 Pan S, Wu X, Jiang J, Gao W, Wan Y, Cheng D, et al. Discovery of NVP-LDE225, a potent and selective smoothened antagonist. ACS Med Chem Lett. 2010 Jun;1(3):130-4.

40 Commissioner $\mathrm{O}$ of the FDA approves first treatment for advanced form of the second most common skin cancer [Internet]. FDA. 2020 Mar https://www.fda.gov/news-events/ press-announcements/fda-approves-firsttreatment-advanced-form-second-mostcommon-skin-cancer-0.

41 Anonymous. Odomzo [Internet]. Eur Medicines Agency. 2018 Sep https://www.ema.europa.eu/en/medicines/human/EPAR/ odomzo.

42 Anonymous. Erivedge [Internet]. Eur Medicines Agency. 2018 Sep https://www.ema.europa.eu/en/medicines/human/EPAR/erivedge.

43 Kim J, Tang JY, Gong R, Kim J, Lee JJ, Clemons $\mathrm{KV}$, et al. Itraconazole, a commonly used antifungal that inhibits Hedgehog pathway activity and cancer growth. Cancer Cell. 2010 Apr;17(4):388-99.

44 Kim DJ, Kim J, Spaunhurst K, Montoya J, Khodosh R, Chandra K, et al. Open-label, exploratory phase II trial of oral itraconazole for the treatment of basal cell carcinoma. J Clin Oncol. 2014 Mar;32(8):745-51.5

45 Sekulic A, Migden MR, Oro AE, Dirix L, Lewis $\mathrm{KD}$, Hainsworth JD, et al. Efficacy and safety of vismodegib in advanced basal-cell carcinoma. N Engl J Med. 2012 Jun;366(23):2171-9.

46 Sekulic A, Migden MR, Basset-Seguin N, Garbe C, Gesierich A, Lao CD, et al. Longterm safety and efficacy of vismodegib in patients with advanced basal cell carcinoma: final update of the pivotal ERIVANCE BCC study. BMC Cancer. 2017 May 16;17(1):332.

47 Teperino R, Amann S, Bayer M, McGee SL, Loipetzberger A, Connor T, et al. Hedgehog partial agonism drives Warburg-like metabolism in muscle and brown fat. Cell. 2012 Oct; 151(2):414-26.

48 Dessinioti C, Antoniou C, Stratigos AJ. From basal cell carcinoma morphogenesis to the alopecia induced by hedgehog inhibitors: connecting the dots. Br J Dermatol. 2017;177(6): 1485-94.

49 Yang H, Cong WN, Yoon JS, Egan JM. Vismodegib, an antagonist of hedgehog signaling, directly alters taste molecular signaling in taste buds. Cancer Med. 2015 Feb;4(2):245-52.

50 Basset-Séguin N, Hauschild A, Kunstfeld R, Grob J, Dréno B, Mortier L, et al. Vismodegib in patients with advanced basal cell carcinoma: primary analysis of STEVIE, an international, open-label trial. Eur J Cancer. 2017;86: $334-48$.

51 Dréno B, Kunstfeld R, Hauschild A, Fosko S, Zloty D, Labeille B, et al. Two intermittent vismodegib dosing regimens in patients with multiple basal-cell carcinomas (MIKIE): a randomised, regimen-controlled, double-blind, phase 2 trial. Lancet Oncol. 2017;18(3):404-12.

52 Migden MR, Guminski A, Gutzmer R, Dirix L, Lewis KD, Combemale P, et al. Treatment with two different doses of sonidegib in patients with locally advanced or metastatic basal cell carcinoma (BOLT): a multicentre, randomised, double-blind phase 2 trial. Lancet Oncol. 2015 Jun;16(6):716-28.

53 Lear JT, Migden MR, Lewis KD, Chang ALS, Guminski A, Gutzmer R, et al. Long-term efficacy and safety of sonidegib in patients with locally advanced and metastatic basal cell carcinoma: 30-month analysis of the randomized phase 2 BOLT study. J Eur Acad Dermatol Venereol. 2018 Mar;32(3):372-81.

54 Atwood SX, Sarin KY, Whitson RJ, Li JR, Kim G, Rezaee M, et al. Smoothened variants explain the majority of drug resistance in basal cell carcinoma. Cancer Cell. 2015 Mar;27(3): 342-53.

55 Pricl S, Cortelazzi B, Dal Col V, Marson D, Laurini E, Fermeglia M, et al. Smoothened (SMO) receptor mutations dictate resistance to vismodegib in basal cell carcinoma. Mol Oncol. 2015 Feb;9(2):389-97.
56 Wang C, Wu H, Evron T, Vardy E, Han GW, Huang XP, et al. Structural basis for smoothened receptor modulation and chemoresistance to anticancer drugs. Nat Commun. 2014 Jul;5:4355.

57 Sharpe HJ, Pau G, Dijkgraaf GJ, Basset-Seguin N, Modrusan Z, Januario T, et al. Genomic analysis of smoothened inhibitor resistance in basal cell carcinoma. Cancer Cell. 2015 Mar;27(3):327-41.

58 Wang C, Wu H, Katritch V, Han GW, Huang XP, Liu W, et al. Structure of the human smoothened receptor bound to an antitumour agent. Nature. 2013 May;497(7449): 338-43.

59 Ching JA, Curtis HL, Braue JA, Kudchadkar RR, Mendoza TI, Messina JL, et al. The impact of neoadjuvant hedgehog inhibitor therapy on the surgical treatment of extensive basal cell carcinoma. Ann Plast Surg. 2015 Jun; 74(Suppl 4):S193-7.

60 Ally MS, Ransohoff K, Sarin K, Atwood SX, Rezaee M, Bailey-Healy I, et al. Effects of combined treatment with arsenic trioxide and itraconazole in patients with refractory metastatic basal cell carcinoma. JAMA Dermatol. 2016 Apr; 152(4):452-6.

61 Therasse P, Arbuck SG, Eisenhauer EA, Wanders J, Kaplan RS, Rubinstein L, et al. New guidelines to evaluate the response to treatment in solid tumors. European Organization for Research and Treatment of Cancer, National Cancer Institute of the United States, National Cancer Institute of Canada. J Natl Cancer Inst. 2000 Feb;92(3):205-16.

62 Eisenhauer EA, Therasse P, Bogaerts J, Schwartz LH, Sargent D, Ford R, et al. New response evaluation criteria in solid tumours: revised RECIST guideline (version 1.1). Eur J Cancer. 2009 Jan;45(2):228-47.

63 Odom D, Mladsi D, Purser M, Kaye JA, Palaka E, Charter A, et al. A matching-adjusted indirect comparison of sonidegib and vismodegib in advanced basal cell carcinoma. J Skin Cancer. 2017;2017:6121760.

64 Calienni MN, Febres-Molina C, Llovera RE, Zevallos-Delgado C, Tuttolomondo ME, Paolino D, et al. Nanoformulation for potential topical delivery of vismodegib in skin cancer treatment. Int J Pharm. 2019 Jun;565:108-22.

65 Skvara H, Kalthoff F, Meingassner JG, WolffWiniski B, Aschauer H, Kelleher JF, et al. Topical treatment of Basal cell carcinomas in nevoid Basal cell carcinoma syndrome with a smoothened inhibitor. J Invest Dermatol. 2011 Aug; 131(8):1735-44.

66 Zhao X, Pak E, Ornell KJ, Pazyra-Murphy MF, MacKenzie EL, Chadwick EJ, et al. A transposon screen identifies loss of primary cilia as a mechanism of resistance to SMO inhibitors. Cancer Discov. 2017;7(12): 1436-49.

67 Whitson RJ, Lee A, Urman NM, Mirza A, Yao CY, Brown AS, et al. Noncanonical hedgehog pathway activation through SRF-MKL1 promotes drug resistance in basal cell carcinomas. Nat Med. 2018;24(3):271-81. 